\title{
Tribological Behavior of Cermet Coatings Deposited from Submicron WC-10Co-4Cr Powders Using HVOF Spraying
}

\author{
Sheng HONG ${ }^{1,2 *}$, Yuping WU ${ }^{1}$, Bo WANG $^{1}$ \\ ${ }^{1}$ College of Mechanics and Materials, Hohai University, 8 Focheng West Road, Nanjing 211100, PR China \\ ${ }^{2}$ Material Corrosion and Protection Key Laboratory of Sichuan Province, 180 Xueyuan Street, Zigong 643000, PR China
}

cross $^{\text {ref }}$ http://dx.doi.org/10.5755/j01.ms.25.3.19507

Received 27 November 2017; accepted 04 April 2018

\begin{abstract}
In this paper, we prepared cermet coatings deposited from submicron WC-CoCr powders using high-velocity oxygenfuel (HVOF) spraying process. The detailed microstructures, slurry erosion and sliding wear resistance of as-sprayed coatings were investigated. The slurry erosion test was performed in a rotating disk rig facility with circulating system using distilled water and $3.5 \mathrm{wt} . \% \mathrm{NaCl}$ slurries. The sliding wear properties were evaluated by a pin-on-disk tribometer under different loads. The results showed that submicron coatings exhibited higher slurry erosion resistance in distilled water slurry than that in $3.5 \mathrm{wt} . \% \mathrm{NaCl}$ slurry after three tests. The slurry erosion mechanism of the coatings was characterized by scratches and pull-out of carbide particle. With increasing load (from $10 \mathrm{~N}$ to $50 \mathrm{~N}$ ), the coatings showed a reduction in average friction coefficient (from 0.52 to 0.44 ), and an increase in mass loss (from $3.3 \mathrm{mg}$ to $11.4 \mathrm{mg}$ ). The evolution of the sliding wear characteristics of the coatings with the increase of the load was microcracks, carbide particle pull-out, spallation, and massive exfoliation. The sliding wear mechanism of the coatings under different loads was primarily abrasive wear.

Keywords: high-velocity oxygen-fuel, WC-10Co-4Cr, submicron, slurry erosion, wear.
\end{abstract}

\section{INTRODUCTION}

Carbon steel has been widely used in marine engineering as one of the most commonly structural metallic materials. Nevertheless, the service life of carbon steel in many industrial applications would decrease when it exposed to sliding wear and slurry erosion, such as steel piles, hydraulic turbines and pumps [1-3]. It is important to select a suitable surface treatment technique to alleviate the deteriorations of carbon steel under service conditions. As a potential application of coating technique, highvelocity oxygen-fuel (HVOF) spraying is a promising thermal spray process to fabricate coatings with high hardness and bond strength, low porosity and oxide content, superior erosion-corrosion and wear resistance [4-7]. Besides, nanostructured WC-Co based coatings could be deposited successfully by HVOF spraying with reduced percentage of detrimental reaction products, which deteriorate corrosion and wear resistance $[8,9]$. Many attempts have been made to improve their properties by optimizing powder structures and spraying parameters [10-12].

Recent studies [6,13-16] have demonstrated that coating porosity, binder composition, flow velocity, and concentration of solid particles are important factors that influence both erosion and corrosion of HVOF sprayed WC-Co based coatings during the slurry erosion-corrosion process. According to Souza and Neville [13-14], HVOF sprayed WC-CoCr coatings can provide good protection against wear and corrosion in liquid-solid impingement when compared with stainless steels, and the role of corrosion and synergy in the total damage was important

\footnotetext{
${ }^{*}$ Corresponding author. Tel.: +86-25-83787233; fax: +86-25-83787233

E-mail address: hongsheng@hhu.edu.cn (S. Hong)
}

on WC-CoCr coating, much more so than on the super duplex stainless steel. They pointed out that the overall erosion-corrosion performance of WC-CoCr coatings can be improved by enhancing their corrosion behavior. Peat et al. [6] compared the synergistic erosion-corrosion behavior of $\mathrm{HVOF}$ sprayed WC-CoCr, $\mathrm{Cr}_{3} \mathrm{C}_{2}-\mathrm{NiCr}$ and $\mathrm{Al}_{2} \mathrm{O}_{3}$ coatings using a jet impingement system and found that WC-CoCr provided enhanced protection over uncoated steel among three coatings. They attributed this to the high hardness, the high resistance to the corrosive effects of the slurry, and the ability of the cobalt matrix to retain the comparably small carbides of WC-CoCr coating. Under sliding wear conditions, the intrinsic structure (e.g. metallic matrix composition, carbide to binder ratio and carbide grain size), the mechanical properties (e.g. hardness, elastic modulus and carbide-binder interfacial strength), and the test conditions (e.g. atmosphere, temperature and load) were found to affect the wear performance of HVOF sprayed WC-Co based coatings [12, 17-20]. To date, most research has focused on the slurry erosion behavior of HVOF sprayed WC-Co based coatings using the jet impingement method, while little work has been conducted on the slurry erosion behavior using rotating disc arrangements method, which is similar to the practical rotation conditions of pump impeller.

In earlier study, we have investigated the evolution of the wear behaviors for HVOF sprayed submicron WC-10Co-4Cr coatings with the change of the temperature [21]. In the current study, the slurry erosion behavior of WC-10Co-4Cr coatings was investigated using rotating disc arrangements method. The mechanisms controlling dry sliding wear of the coatings under different loads were also evaluated. 


\section{EXPERIMENTAL PROCEDURE}

A commercially available submicron WC-10 wt.\% Co-4 wt.\% Cr powder (Infralloy-7410, Inframat Advanced Materials Corp., Farmington, CT, USA) was coated on the AISI 1045 steel substrate by HVOF spray system (Praxair Tafa-JP8000, USA). The spray parameters used in the present study were conducted at a spray distance of 330 $\mathrm{mm}$, an oxygen flow rate of $944 \mathrm{~L} \cdot \mathrm{min}^{-1}$, a kerosene flow rate of $0.38 \mathrm{~L} \cdot \mathrm{min}^{-1}$, an argon carrier gas flow rate of $10.86 \mathrm{~L} \cdot \mathrm{min}^{-1}$, a powder feed rate of $5 \mathrm{rpm}$, and a spray gun speed of $280 \mathrm{~mm} \cdot \mathrm{s}^{-1}$. The thickness of tested coating was about $200 \mu \mathrm{m}$. Then the coating specimens were wire cut, ground and polished for slurry erosion and wear testing.

The microstructures of the as-received powder and assprayed coating were observed by a scanning electron microscope (SEM, Hitachi S-3400N, Japan). Finer-scale microstructural characterization of the coating was performed using a high-resolution transmission electron microscope (HRTEM, JEOL JEM-2100F, Japan) operated at $200 \mathrm{kV}$.

The slurry erosion experiments were carried out using a rotating disk rig facility with circulating system. The details of the slurry erosion test apparatus and its specimen's dimension have been reported [22]. Prior to the test, specimens with an average surface roughness $\mathrm{Ra}=0.02 \mu \mathrm{m}$ were cleaned with acetone in an ultrasonic bath, dried in hot air, and weighed by an electronic balance. Then, specimens were fixed on the disk that was controlled by a motor. In the testing process, the slurry solution consisted of water and commercial silica sand with the hardness of $1050-1220 \mathrm{HV}_{0.1}$ and the grain size of $100-220 \mu \mathrm{m}$. The slurry solution containing $3.5 \mathrm{wt} . \%$ $\mathrm{NaCl}$ and silica sand was also used for comparison. The sand concentration and the rotation speed of specimen were $10 \mathrm{~kg} \cdot \mathrm{m}^{-3}$ and $18 \mathrm{~m} \cdot \mathrm{s}^{-1}$, respectively. The slurry erosion test time was set to a constant value of $10 \mathrm{~h}$. After each slurry erosion test, specimens were degreased, rinsed, dried and weighed periodically by an analytical balance with an accuracy of $0.1 \mathrm{mg}$ to determine mass loss. The surface morphologies of specimens after slurry erosion were observed by SEM with an energy dispersive spectroscopy (EDS, EX250).

The friction and wear experiments were carried out using a MG-2000 pin-on-disk tribometer (Beilun Balancing Machinery Co. Ltd., Zhangjiakou, China), according to standard ASTM G99-05 [23]. The preparation of the coating specimens was as same as that prior to the slurry erosion test. In the wear test, the counterface disk $(\Phi$ $45 \mathrm{~mm} \times 7 \mathrm{~mm}$ ) was rotated, while the upper pin of $\mathrm{Al}_{2} \mathrm{O}_{3}$ ball $(\Phi 6 \mathrm{~mm})$ was stationary. Mating materials were HVOF sprayed submicron WC-10Co-4Cr coatings. In order to investigate the effects of load on the sliding wear behaviors of the coatings, different wear conditions were obtained by varying the load and keeping the sliding velocity at $0.9 \mathrm{~m} \cdot \mathrm{s}^{-1}$. Each test was carried out for up to a sliding distance of $1500 \mathrm{~m}$ at laboratory atmosphere (temperature $20-25{ }^{\circ} \mathrm{C}$, relative humidity of $40-50 \%$ ) without lubrication. The frictional moments were recorded by a computer consistently. The wear mass loss of the specimens was determined by using an analytical balance with an accuracy of $0.1 \mathrm{mg}$ before and after the test. The worn surfaces of the coatings were characterized by SEM. Both slurry erosion and sliding wear tests were repeated thrice to ensure the reproducibility and validity of the experiment result.

\section{RESULTS AND DISCUSSION}

\subsection{Microstructural characterization}

Fig. 1 shows the microstructures of submicron WC-10Co-4Cr powders and coatings. SEM morphologies of the shape and cross-section of powder grains are shown in Fig. $1 \mathrm{a}$ and b, respectively. It can be seen that the feedstock powder grains exhibit nearly spherical shape in size range of $5-45 \mu \mathrm{m}$, which is suitable for HVOF spraying process. The submicron powder agglomerate has a relatively dense structure with some limited internal porosity. The particle size of the WC particles is less than $500 \mathrm{~nm}$. It is evident from Fig. $1 \mathrm{c}$ that the coating presents a uniform microstructure of low porosity. Further TEM investigation (Fig. 1 d) reveals that coexistence of amorphous phase and nanoclusters is observed and the dimension of the nanoclusters is less than $20 \mathrm{~nm}$. A similar morphology has been observed in other HVOF sprayed coatings [24].

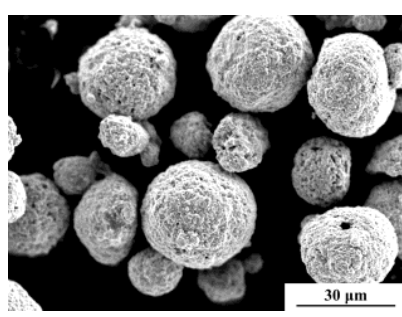

a

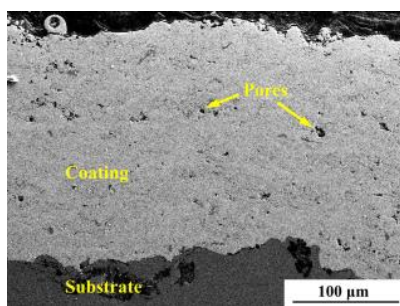

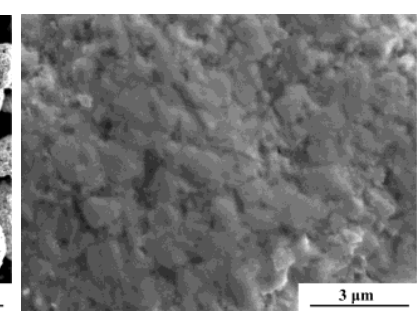

b

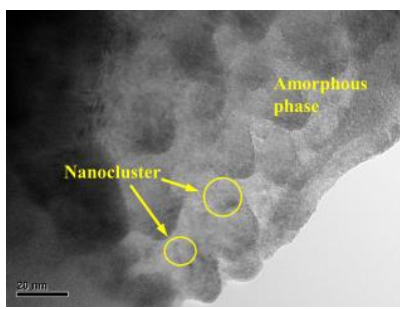

d
Fig. 1. Microstructures of submicron WC-10Co-4Cr powders and coatings: a-SEM image of powder grains; $b$-SEM image of cross-section of powder grains; $c$-SEM image of cross-section of HVOF sprayed coating; d-TEM image of microstructure of HVOF sprayed coating

\subsection{Slurry erosion performance}

Fig. 2 shows the mass loss rates using two different slurry solutions (i.e. distilled water $+10 \mathrm{~kg} \cdot \mathrm{m}^{-3}$ silica and $3.5 \mathrm{wt} \% \mathrm{NaCl}+10 \mathrm{~kg} \cdot \mathrm{m}^{-3}$ silica) for $\mathrm{HVOF}$ sprayed submicron WC-10Co-4Cr coatings, from which a significant influence of $\mathrm{NaCl}$ concentration on the slurry erosion process can be deduced. After eroded for $10 \mathrm{~h}$, the mass loss rates of the coatings in $3.5 \mathrm{wt} \% \mathrm{NaCl}$ slurry and distilled water slurry were $0.22 \mathrm{mg} \cdot \mathrm{cm}^{-2} \cdot \mathrm{h}^{-1}$ and $0.13 \mathrm{mg} \cdot \mathrm{cm}^{-2} \cdot \mathrm{h}^{-1}$, respectively. It is clear that the mass loss rate of the coatings in $3.5 \mathrm{wt} . \% \mathrm{NaCl}$ slurry is higher than 
that in distilled water slurry, which is attributed to both uniform corrosion and pitting corrosion of the coating under the combined action of slurry erosion and corrosion $[13,22]$. The cummulative weight wear curves for the coatings in different slurry solutions are shown in Fig. 3. It revealed that there was no evidence of running-in period for the coatings in both slurry solutions.

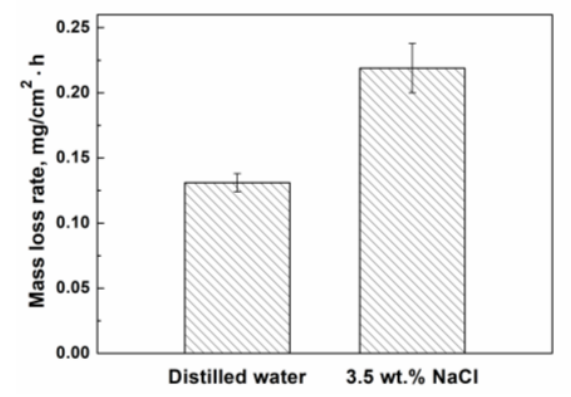

Fig. 2. Variation of mass loss rate with $\mathrm{NaCl}$ concentration for HVOF sprayed submicron WC-10Co-4Cr coatings at $18 \mathrm{~m} \cdot \mathrm{s}^{-1}$ (sand content: $10 \mathrm{~kg} \cdot \mathrm{m}^{-3}$, sand size: $100-220 \mu \mathrm{m})$

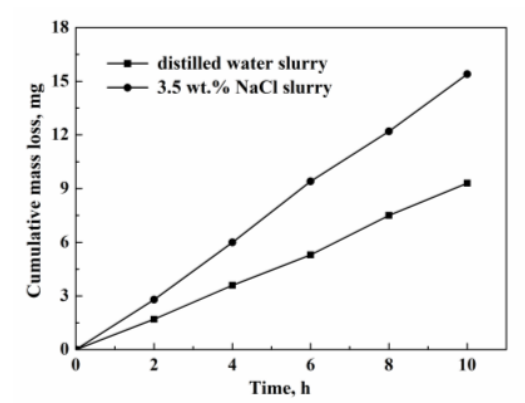

Fig. 3. Cumulative mass losses for HVOF sprayed submicron WC-10Co-4Cr coatings at $18 \mathrm{~m} \cdot \mathrm{s}^{-1}$ in distilled water and 3.5 wt. $\% \mathrm{NaCl}$ slurries (sand content: $10 \mathrm{~kg} \cdot \mathrm{m}^{-3}$, sand size: $100-220 \mu \mathrm{m})$

To get an insight into the slurry erosion mechanisms for $\mathrm{HVOF}$ sprayed submicron WC-10Co-4Cr coatings in different slurry solutions, the eroded surface of samples was studied by SEM. Fig. 4 shows typical morphological features of the coatings after slurry erosion tests for $10 \mathrm{~h}$ in distilled water and $3.5 \mathrm{wt} . \% \mathrm{NaCl}$ slurries. It can be noticed from Fig. $4 \mathrm{a}$ and $\mathrm{c}$ that scratches were detected on the surface of the coating along flow direction due to the repetitive impacts of sand particles. As compared with the surface of the coating in distilled water slurry, several severe scratched scars and oxide scales distributed on whole specimen surface of the coating in $3.5 \mathrm{wt} \% \mathrm{NaCl}$ slurry. Besides the scratches, a number of the pull-out of carbide particle on the surface was clear in Fig. 4 b and d, which may have occurred due to the fatigue mechanism. These results reflected that the mass loss of the coatings resulted from the scratches and the pull-out of carbide particle. The EDS spectrum and quantitative analysis revealed that the corrosion products (region recognized by the dark gray color) mainly appeared at the carbide-binder interface, which formed as a result of localized corrosion after the penetration of chloride ions during the erosioncorrosion process. This phenomenon was similar to the results reported by other researchers $[16,25]$. a

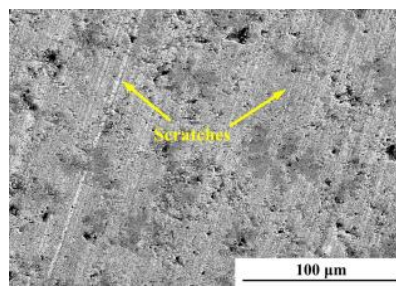

c

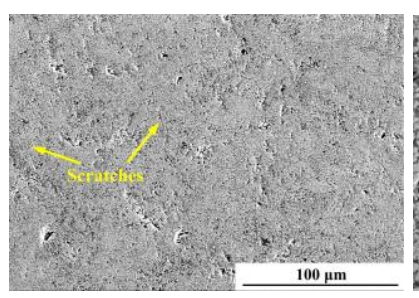

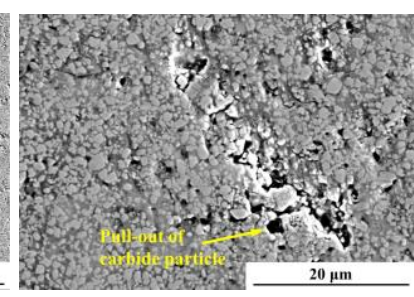

b

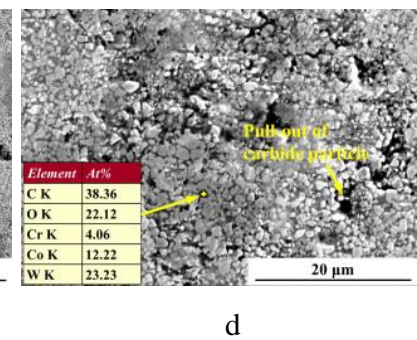

Fig. 4. SEM images of HVOF sprayed submicron WC-10Co-4Cr coatings after slurry erosion for $10 \mathrm{~h}$ at $18 \mathrm{~m} \cdot \mathrm{s}^{-1}$ in distilled water (a, b) and 3.5 wt. $\% \mathrm{NaCl}$ (c, d) slurries (sand content: $10 \mathrm{~kg} \cdot \mathrm{m}^{-3}$, sand size: $100-220 \mu \mathrm{m}$ )

\subsection{Friction and wear properties}

The variation of friction coefficients with the sliding distance for HVOF sprayed submicron WC-10Co-4Cr coatings under different loads are shown in Fig. 5. It can be observed that all the friction coefficient curves of the coatings possessed the running-in period and the steadystate period. A similar phenomenon was observed by other researchers [26]. Duration of the running-in period for the coatings was increased with increasing load. This could be explained by the high local contact pressures between the coatings and the alumina counterparts which results in longer time to reach an equilibrium state at a higher load [20]. The average friction coefficients during the steady period of the coatings decreased from 0.52 to 0.44 when the load increased from $10 \mathrm{~N}$ to $50 \mathrm{~N}$. The reason is that the high flow ability of ductile $\mathrm{Co}-\mathrm{Cr}$ matrix significantly influenced the actual contact area between the coating and the $\mathrm{Al}_{2} \mathrm{O}_{3}$ ceramic after the long-term action of high load contact. It will cause the formation of mechanically mixed layer which can increase the actual contact area and reduce the friction coefficient $[27,28]$.

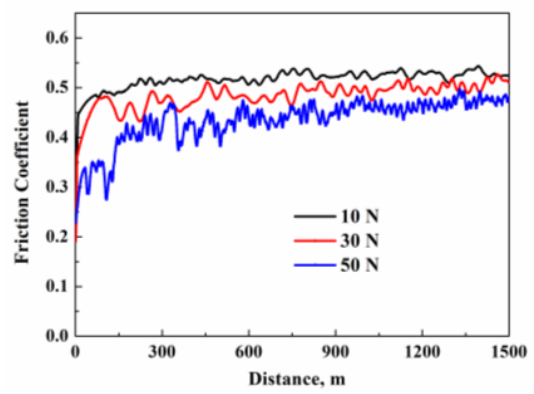

Fig. 5. Friction coefficients varied with sliding distance for HVOF sprayed submicron WC-10Co-4Cr coatings under different loads (counterface $\mathrm{Al}_{2} \mathrm{O}_{3}$, room temperature, sliding velocity $\left.0.9 \mathrm{~m} \cdot \mathrm{s}^{-1}\right)$

Fig. 6 shows the wear cumulative mass loss curves for HVOF sprayed submicron WC-10Co-4Cr coatings under different loads. The mass losses of the coatings after 
$1500 \mathrm{~m}$ of the sliding wear testing under different loads are $3.3 \mathrm{mg}, 6.4 \mathrm{mg}$ and $11.4 \mathrm{mg}$, respectively. It is evident that the mass loss of the coating increased nearly four times when the load increased from $10 \mathrm{~N}$ to $50 \mathrm{~N}$, indicating that the oxidation level of the contact surfaces was relatively low at the present tribological conditions. According to Ma et al. [29], the decrease of wear rate of the carbide cermet coatings with increasing the applied load (from $49 \mathrm{~N}$ to $245 \mathrm{~N}$ ) was related to the large frictional heat and the high oxidation level of the contact surfaces. However, in the present study, as the load increased, more severe damage of the coating occurred during the sliding wear process without a large fraction of tribo-oxidation film on the worn surface [30].

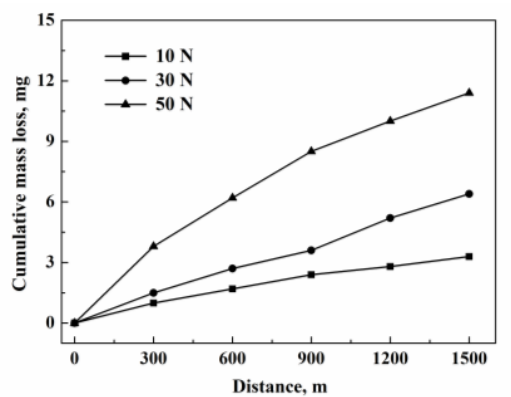

Fig. 6. Cumulative mass losses for HVOF sprayed submicron WC-10Co-4Cr coatings under different loads (counterface $\mathrm{Al}_{2} \mathrm{O}_{3}$, room temperature, sliding velocity $0.9 \mathrm{~m} \cdot \mathrm{s}^{-1}$ )

Fig. 7 shows typical morphological features from worn surfaces of HVOF sprayed submicron WC-10Co-4Cr coatings against $\mathrm{Al}_{2} \mathrm{O}_{3}$ ball under different loads.
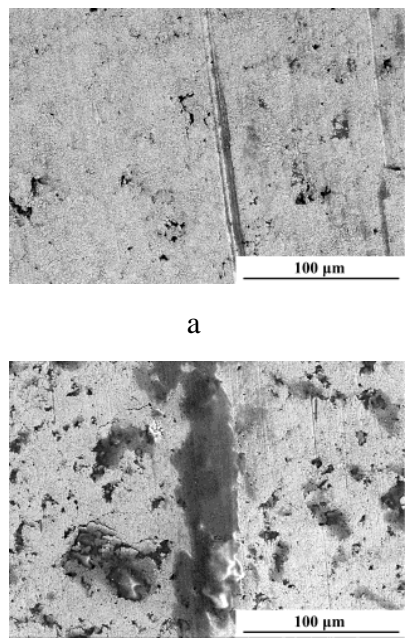

c

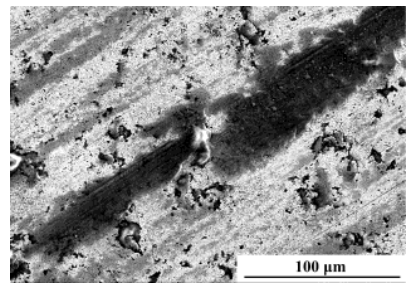

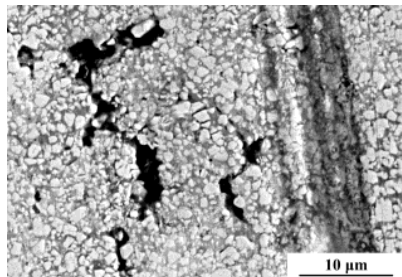

b

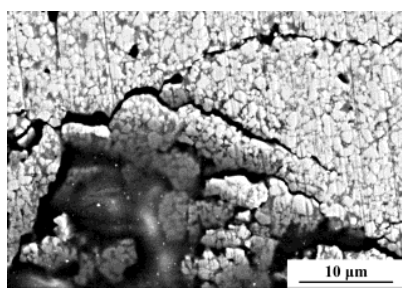

d

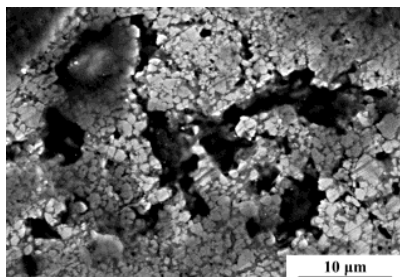

f
Fig. 7. SEM images of HVOF sprayed submicron WC-10Co-4Cr coatings after sliding wear for $1500 \mathrm{~m}$ under different loads: $a, b-10 \mathrm{~N} ; \mathrm{c}, \mathrm{d}-30 \mathrm{~N} ; \mathrm{e}, \mathrm{f}-50 \mathrm{~N}$
From Fig. 7 a, it can be noticed that the worn surface of the coating was relatively smooth after sliding under $10 \mathrm{~N}$ for $1500 \mathrm{~m}$. Further observation shows that small amount of pits, micro-cracks and shallow furrows were recorded on the surface of the coating, as shown in Fig. 7 b. This indicates that ductile binder phases effectively inhibited the propagation of cracks and protected the hard phases during sliding process under relatively low load. Fig. $7 \mathrm{c}$ shows that the width of worn track slightly increased and spallation appeared on the surface of worn track as the test load increased from $10 \mathrm{~N}$ to $30 \mathrm{~N}$. There were also some fine particles on the worn surface (Fig. $7 \mathrm{~d}$ ), which was attributed to the excessive grooving of the coating surface as a result of the interaction between the asperities on the hard $\mathrm{Al}_{2} \mathrm{O}_{3}$ ceramic and the coating surface [31]. In the case of $50 \mathrm{~N}$ (Fig. $7 \mathrm{e}$ and f), there are numerous pull-out of carbide particle and massive exfoliation of materials in a widespread dispersion on the worn surface, which give contribution to the overall wear rate of the coating. This may be associated with the enhanced compaction that induced a severely worn of both binder phases and carbide grains $[32,33]$. Based on the above analysis, micro-cracks, carbide particle pull-out, spallation, and massive exfoliation contributed to the evolution of the sliding wear characteristics of the submicron coating with the increase of the load. The sliding wear mechanism of the coatings under different loads was primarily abrasive wear.

\section{CONCLUSIONS}

HVOF sprayed submicron WC-10Co-4Cr coatings exhibited higher slurry erosion resistance in distilled water slurry than that in $3.5 \mathrm{wt} . \% \mathrm{NaCl}$ slurry, the mass loss rates of the coatings in $3.5 \mathrm{wt} . \% \mathrm{NaCl}$ slurry and distilled water slurry were $0.22 \mathrm{mg} \cdot \mathrm{cm}^{-2} \cdot \mathrm{h}^{-1}$ and $0.13 \mathrm{mg} \cdot \mathrm{cm}^{-2} \cdot \mathrm{h}^{-1}$, respectively. The slurry erosion mechanism of the coatings involved selective erosion of the binder phases and brittle fracture of the carbides, which was characterized by scratches and pull-out of carbide particles. The average friction coefficients of the coatings decreased from 0.52 to 0.44 when the load increased from $10 \mathrm{~N}$ to $50 \mathrm{~N}$. With increment of load, the mass losses of the coatings increased. The characteristics involved in the sliding wear process of the coatings with the increase of the load were micro-cracks, carbide particle pull-out, spallation, and massive exfoliation. The sliding wear mechanism of the coatings under different loads was primarily abrasive wear. At slurry erosion as well at sliding wear removal of binder material besides the scratching may occur due to the fatigue mechanism.

\section{Acknowledgments}

The research was supported by the National Natural Science Foundation of China (Grant Nos. 51609067 and 51579087), the Fundamental Research Funds for the Central Universities (Grant No. 2018B17014), the Natural Science Foundation of Jiangsu Province of China (Grant No. BK20150806), and the Opening Project of Material Corrosion and Protection Key Laboratory of Sichuan Province (Grant No. 2016CL08). Professor Yugui Zheng 
of Institute of Metal Research, Chinese Academy of Sciences was also acknowledged for providing slurry erosion equipment.

\section{REFERENCES}

1. Wood, R.J.K. Erosion-corrosion Interactions and Their Effect on Marine and Offshore Materials Wear 261 2010: pp. $1012-1023$.

https://doi.org/10.1016/j.wear.2006.03.033

2. Löbel, M., Lindner, T., Mehner, T., Lampke, T. Microstructure and Wear Resistance of AlCoCrFeNiTi High-entropy Alloy Coatings Produced by HVOF Coatings 7 (9) 2017: pp. 144. https://doi.org/10.3390/coatings7090144

3. Solecka, M., Kopyściański, M., Kusiński, J., Kopia, A., Radziszewska, A. Erosive Wear of Inconel 625 Alloy Coatings Deposited by CMT Method Archives of Metallurgy and Materials 61 (2) 2016: pp. 1201-1206. https://doi.org/10.1515/amm-2016-0199

4. Surzhenkov, A., Goljandin, D., Traksmaa, R., Viljus, M., Talviste, K., Aruniit, A., Latokartano, J., Kulu, P. High Temperature Erosion Wear of Cermet Particles Reinforced Self-fluxing Alloy HVOF Sprayed Coatings Materials Science (Medžiagotyra) 21 (3) 2015: pp. 386-390. https://doi.org/10.5755/j01.ms.21.3.7617

5. Żórawski, W. The Microstructure and Tribological Properties of Liquid-fuel HVOF Sprayed Nanostructured WC-12Co Coatings Surface and Coatings Technology 220 2013: pp. 276-281.

https://doi.org/10.1016/j.surfcoat.2012.11.007

6. Peat, T., Galloway, A.M., Toumpis, A.I., Harvey, D. Evaluation of The Synergistic Erosion-corrosion Behaviour of HVOF Thermal Spray Coatings Surface and Coatings Technology 299 2016: pp. 37-48. https://doi.org/10.1016/j.surfcoat.2016.04.072

7. Zavareh, M.A., Sarhan, A.A.D.M., Zavareh, P.A., Basirun, W.J. Electrochemical Corrosion Behavior of Carbon Steel Pipes Coated with a Protective Ceramic Layer using Plasma and HVOF Thermal Spray Techniques for Oil and Gas Ceramics International 42 2016: pp. 3397-3406.

https://doi.org/10.1016/j.ceramint.2015.10.134

8. Żórawski, W., Makrenek, M., Góral, A. Mechanical Properties and Corrosion Resistance of HVOF Sprayed Coatings using Nanostructured Carbide \} Powders Archives of Metallurgy and Materials 61 (4) 2016: pp. $1839-1846$. https://doi.org/10.1515/amm-2016-0297

9. Hong, S., Wu, Y.P., Zheng, Y.G., Wang, B., Gao, W.W., Lin, J.R. Microstructure and Electrochemical Properties of Nanostructured WC-10Co-4Cr Coating prepared by HVOF Spraying Surface and Coatings Technology 235 2013: pp. $582-588$.

https://doi.org/10.1016/j.surfcoat.2013.08.029

10. Thakura, L., Arora, N., Jayaganthan, R., Sood, R. An Investigation on Erosion Behavior of HVOF Sprayed WC$\mathrm{CoCr}$ Coatings Applied Surface Science 258 2011: pp. $1225-1234$. https://doi.org/10.1016/j.apsusc.2011.09.079

11. Hong, S., Wu, Y.P., Wang, B., Zheng, Y.G., Gao, W.W., Li, G.Y. High-velocity Oxygen Fuel Spray Parameter Optimization of Nanostructured WC-10Co-4Cr Coatings and Sliding Wear Behavior of the Optimized Coating Materials and Design 55 2014: pp. 286-291.

https://doi.org/10.1016/j.matdes.2013.10.002
12. Wesmann, J.A.R., Espallargas, N. Effect of Atmosphere, Temperature and Carbide Size on the Sliding Friction of Self-mated HVOF WC-CoCr Contacts Tribology International 101 2016: pp. 301-313. https://doi.org/10.1016/j.triboint.2016.04.032

13. de Souza, V.A., Neville, A. Corrosion and Erosion Damage Mechanisms during Erosion-corrosion of WC-Co-Cr Cermet Coatings Wear 255 2003: pp. 146-156. https://doi.org/10.1016/S0043-1648(03)00210-2

14. de Souza, V.A., Neville, A. Corrosion and Synergy in a WC-Co-Cr HVOF Thermal Spray Coating-Understanding Their Role in Erosion-corrosion Degradation Wear 259 2005: pp. $171-180$ https://doi.org/10.1016/j.wear.2004.12.003

15. Berget, J., Rogne, T., Bardal, E. Erosion-corrosion Properties of Different WC-Co-Cr Coatings Deposited by the HVOF Process-Influence of Metallic Matrix Composition and Spray Powder Size Distribution Surface and Coatings Technology 201 2007: pp. 7619-7625. https://doi.org/10.1016/j.surfcoat.2007.02.032

16. Saha, G.C., Khan, T.I., Zhang, G.A. Erosion-corrosion Resistance of Microcrystalline and Near-nanocrystalline WC-17Co High Velocity Oxy-fuel Thermal Spray Coatings Corrosion Science 53 2011: pp. 2106-2114. https://doi.org/10.1016/j.corsci.2011.02.028

17. Dent, A.H., DePalo, S., Sampath, S. Examination of the Wear Properties of HVOF Sprayed Nanostructured and Conventional WC-Co Cermets with Different Binder Phase Contents Journal of Thermal Spray Technology 11 (4) 2002: pp. $551-558$. https://doi.org/10.1361/105996302770348691

18. Picas, J.A., Punset, M., Baile, M.T., Martin, E., Forn, A. Tribological Evaluation of HVOF Thermal-spray Coatings as a Hard Chrome Replacement Surface and Interface Analysis 43 2011: pp. 1346-1353. https://doi.org/10.1002/sia.3721

19. Geng, Z., Li, S., Duan, D.L., Liu, Y. Wear Behavior of WC-Co HVOF Coatings at Different Temperatures in Air and Argon Wear 330-331 2015: pp. 348-353. https://doi.org/10.1016/j.wear.2015.01.035

20. Wang, H.B., Wang, X.Z., Song, X.Y., Liu, X.M., Liu, X.W. Sliding Wear Behavior of Nanostructured WCCo-Cr Coatings Applied Surface Science 355 2015: pp. $453-460$ https://doi.org/10.1016/j.apsusc.2015.07.144

21. Hong, S., Wu, Y.P., Wang, B., Zhang, J.F., Zheng, Y., Qiao, L. The Effect of Temperature on the Dry Sliding Wear Behavior of HVOF Sprayed Nanostructured WC-CoCr Coatings Ceramics International 43 2017: pp. 458-462. https://doi.org/10.1016/j.ceramint.2016.09.180

22. Wang, Y., Zheng, Y.G., Ke, W., Sun, W.H., Hou, W.L., Chang, X.C., Wang, J.Q. Slurry Erosion-corrosion Behaviour of High-velocity Oxy-fuel (HVOF) Sprayed Febased Amorphous Metallic Coatings for Marine Pump in Sand-containing $\mathrm{NaCl}$ Solutions Corrosion Science 53 2011: pp. 2106-3185. https://doi.org/10.1016/j.corsci.2011.05.062

23. ASTM G99-05, Standard Test Method for Wear Testing with a Pin-on-Disk Apparatus, ASTM International, West Conshohocken, PA, 2010. https://doi.org/10.1520/G0099-05

24. Sharma, P., Majumdar, J.D. Microstructural Characterization and Properties Evaluation of Ni-based Hardfaced Coating on AISI 304 Stainless Steel by High 
Velocity Oxyfuel Coating Technique Metallurgical and Materials TransactionsA 44A (1) 2013: pp. 372-380.

https://doi.org/10.1007/s11661-012-1407-y

25. Goyal, D.K., Singh, H., Kumar, H., Sahni, V. Slurry Erosion Behavior of HVOF Sprayed WC-10Co-4Cr and $\mathrm{Al}_{2} \mathrm{O}_{3}+13 \mathrm{TiO}_{2}$ Coatings on a Turbine Steel Wear 289 2012: pp. $46-57$.

https://doi.org/10.1016/j.wear.2012.04.016

26. Zhu, Y.C., Yukimura, K., Ding, C.X., Zhang, P.Y. Tribological Properties of Nanostructured and Conventional WC-Co Coatings Deposited by Plasma Spraying Thin Solid Films 388 2001: pp. 277-282. https://doi.org/10.1016/S0040-6090(01)00805-7

27. Du, H., Sun, C., Hua, W.G., Wang, T.G., Gong, J., Jiang, X., Lee, S.W. Structure, Mechanical and Sliding Wear Properties of WC-Co/MoS $2-\mathrm{Ni}$ Coatings by Detonation Gun Spray Materials Science and Engineering A 445-446 2007: pp. 122-134. https://doi.org/10.1016/j.msea.2006.09.011

28. Rajinikanth, V., Venkateswarlu, K. An Investigation of Sliding Wear Behavior of WC-Co Coating Tribology International 44 2011: pp. 1711-1719. https://doi.org/10.1016/j.triboint.2011.06.021

29. Ma, N., Guo, L., Cheng, Z.X., Wu, H.T., Ye, F.X., Zhang, K.K. Improvement on Mechanical Properties and Wear Resistance of HVOF Sprayed WC-12Co Coatings by
Optimizing Feedstock Structure Applied Surface Science 320 2014: pp. $364-371$.

https://doi.org/10.1016/j.apsusc.2014.09.081

30. Yu, H.L., Zhang, W., Wang, H.M., Guo, Y.M., Wei, M., Song, Z.Y., Wang, Y. Bonding and Sliding Wear Behaviors of the Plasma Sprayed NiCrBSi Coatings Tribology International 66 2013: pp. 105-113.

https://doi.org/10.1016/j.triboint.2013.04.017

31. de Villiers Lovelock, H.L. Powder/processing/structure Relationship in WC-Co Thermal Spray Coatings: A Review of the Published Literature Journal of Thermal Spray Technology 7 1998: pp. 357-373. https://doi.org/10.1361/105996398770350846

32. Tyagi, R., Xiong, D.S., Li, J.L. Effect of Load and Sliding Speed on Friction and Wear Behavior of Silver/h-BN Containing Ni-base P/M Composites Wear 270 2011: pp. $423-430$.

https://doi.org/10.1016/j.wear.2010.08.013

33. Kong, D.J., Zhao, B.G. Effects of Loads on Friction-wear Properties of HVOF Sprayed NiCrBSi Alloy Coatings by Laser Remelting Journal of Alloys and Compounds 705 2017: pp. 700-707.

https://doi.org/10.1016/j.jallcom.2017.02.171 